\title{
МОЖЛИВІСТЬ ПІДВИЩЕННЯ МОЛОЧНОЇ ПРОДУКТИВНОСТІ КОРІВ УКРАЇНСЬКОЇ ЧОРНО-РЯБОЇ МОЛОЧНОЇ ПОРОДИ ЗА РАХУНОК СЕЛЕКЦІЙНО-ТЕХНОЛОГІЧНИХ ЧИННИКІВ
}

Желізняк Іван Миколайович

ст. викладач

Полтавська державна аграрна академія ORCID: https://orcid.org/0000-0002-1515-0541

Email: zhim@ukr.net

Войтенко Світлана Леонідівна

доктор сільськогосподарських наук, професор Інститут розведення і генетики тварин імені М.В.Зубця НААН ORCID: https://orcid.org/0000-0002-7196-8700

Email: slvoitenko@ukr.net

Карунна Тетяна Іванівна кандидат сільськогосподарських наук Полтавська державна аграрна академія ORCID: https://orcid.org/ 0000-0001-9290-8961 Email: popovycht7@gmail.com

Враховуючи, що підвищення продуктивності великої рогатої худоби в значній мірі обумовлюється закономірностями прояву генотипу тварин в певних умовах, вбачалося актуальним встановлення зв'язку бугая з молочною продуктивністю дочок, які продукували молоко в умовах сучасної прогресивної технології та збалансованого рівня годівлі, а також впливу технології на мінливість і консолідованість ліній за надоєм. Дослідженнями встановлено, що прогресивна технологія виробництва молока у сумі із племінною цінністю бугаїв-поліпшувачів забезпечили коровам дочкам бугаїв Б.Е.Кенні, Б.Патча, В.Б.Секвойя, Д.Фрості, Л.Марселлюса, П.Гілморе, Р.Поттера, С.Д.Ларіата, С.Стінга і Х.Пеппера реалізаційний потенціал надою першої лактації більше ніж 7000 кг молока, а Дж. А. Пінга і Х.Віндбрейкера - 8000 ке. Низька молочна продуктивність дочок окремих плідників ймовірно обумовлюється не поєднуваністю батьківської основи та низькою племінною цінністю самих бугаїв. Не встановлено чіткої закономірності підвищення надою корів другої лактації, порівняно із першою у залежності від походження за батьком. Найвищий реалізаційним потенціал надою другої лактації своїм дочкам забезпечив бугай Дж. А. Піне, від яких за 305 днів лактації одержано 10898ке молока, що на 2624ка (P>0,99) більше первісток. Порівняльний аналіз мінливості одних і тих самих ліній за надоєм засвідчив значну різницю між селекційними групами у межах конкретного господарства за майже не суттєвої різниці між стадами, що дало змогу зробити висновок про відсутність впливу технологій виробництва молока на мінливість ліній. Визначений рівень фенотипової консолідованості ліній за надоєм засвідчив не однорідність більшості генеалогічних фрормувань у межах стада, але при цьому визнано, що консолідованість тварин за надоєм не залежить від прийнятої технології виробництва молока, а обумовлена іншими чинниками.

Ключові слова: корови, лінія, молочна продуктивність, вплив бугая, технологія, мінливість, френотипова консолідованість.

Підвищення продуктивності корів в умовах сучасного виробництва молока пов'язано із створенням тваринам належних умов утримання, забезпеченням збалансованим рівнем годівлі, автоматизацією та механізацією технологічних процесів, зниженням витрат праці на виробництво продукції, а також вибором породи, як засобу виробництва та подальшими методами селекційної роботи, спрямованими на прояв генетичного потенціалу тварин. На думку багатьох дослідників, прояв генетичного потенціалу корів за молочною продуктивністю обумовлюється широким спектром чинників, починаючи від зовнішнього середовища, в якому знаходиться корова і закінчуючи її генотипом, тобто комплексом генів, які успадковуються від батьків і обумовлюють дію відповідної ознаки продуктивності $[15,20,25,28$, 29]. Доведено, що продуктивність тварин знаходиться у тісній взаємодії генотипу й довкілля і для ії поліпшення потрібні новітні технології, які б враховували біологічні особ- ливості живого організму. В свою чергу, новітні технології виробництва молока пред'являють підвищені вимоги до худоби молочних порід, які повинні характеризуватися високим рівнем молочної продуктивності, придатністю до машинного доїння, тривалістю господарського використання, резистентністю тощо $[10,16,19,24,31]$. Українські породи великої рогатої худоби молочного напряму продуктивності мають високий генетичний потенціал за надоєм $[3,8,19,20]$, але умови довкілля не сприяють реалізації його в повній мірі. Встановлено, що навіть в одній кліматичній зоні, але різних господарств корови української чорно-рябої молочної породи за лактацію продукували різну кількість молока. Доведена не можливість створення консолідованих стад за молочною продуктивністю без урахування лінії, плідники якої забезпечують своїм дочкам прояв генетичного потенціалу [4].

3 урахуванням чого дослідження питань впро-

Вісник Сумського національного аграрного університету 
вадження сучасних технологій у молочному скотарстві та їх вплив на мінливість і консолідованість ліній, а також виявлення бугаїв-поліпшувачів за продуктивністю корів дочок $\epsilon$ актуальним і має практичну цінність.

Українська чорно-ряба молочна порода, яка відноситься до однієї з найбільш поширених на теренах України, в своїй структурі нараховує декілька внутрішньопородних і заводських типів $[3,8,13,26]$, що сприяє підтриманню в популяції високої генетичної мінливості, формуванню різних екстер'єрних типів, створенню передумов для формування нових структурних одиниць породи, які були б адаптовані до сучасних технологій з їх механізацією та автоматизацією.

Ефективність селекції з породою відображається у створенні популяції, яка консолідована на генотиповому і фенотиповому рівні [17]. Саме тому проблемі консолідації тварин в конкретному стаді чи породі присвячено досить багато робіт науковців $[11,21,26]$, але який саме ступінь фенотипової консолідації забезпечать генетичний прогрес популяції не встановлено. 3 урахуванням чого добір тварин в стаді за відповідною ознакою продуктивності потрібно узгоджувати із ступенем фенотипової консолідованості тварин.

Досвід ведення молочного скотарства переконує, що лише в умовах сучасних прогресивних технологій виробництва продукції можна одержати від корови максимальну, генетично запрограмовану кількість молока. Застосування традиційних (старих) технологій з прив'язним утриманням корів та доїнням у стійлах знижує конкурентоспроможність галузі і робить її непривабливою [19, 27]. Порівняльний аналіз продуктивності корів, які належали до одних і тих самих ліній, але утримувалися за різних технологій, засвідчив достовірну перевагу прогресивної технології [4].

Дослідженнями науковців встановлено, що серед селекційно-генетичних чинників впливу на молочну продуктивність корів найбільш обґрунтованими вважаються успадковуваність ознак, методи оцінки племінної цінності бугаїв, зв'язок селекційної цінності бугаїв 3 молочною продуктивністю їх дочок, поєднуваність ліній тощо [1, 7, 9, 12, 14]. Доведений переважаючий вплив бугаїв-поліпшувачів на потомство, який становив 71,3-73,0\%, що значно вище впливу матерів [22].

Враховуючи, що підвищення продуктивності великої рогатої худоби, в значній мірі, обумовлюється закономірностями прояву генотипу тварин в певних умовах, нами вбачалося актуальним встановлення зв'язку бугая з молочною продуктивністю дочок, які продукували молоко в умовах сучасної прогресивної технології та збалансованого рівня годівлі, а також впливу технології на мінливість і консолідованість ліній за надоєм.

Мета досліджень полягала у визначенні бугаїв голштинської породи, які в умовах промислової технології виробництва молока забезпечували своєму потомству найвищу молочну продуктивність, а також впливу технології виробництва молока на фенотипову консолідованість та мінливості ліній.

Матеріали та методи досліджень. Експериментальні дослідження виконані на коровах української чорнорябої молочної породи в умовах ТОВ «Гоголево» і ТОВ «Шишацька», які $€$ структурними підрозділами ТОВ «АФ ім. Довженко» агрохолдингу «Астарта-Київ». Технологія виробництва молока в ТОВ «Гоголево» сучасна прогресивна 3 безприв'язним утриманням корів і доїнням в доїльній залі на установці «Ялинка», а в ТОВ «Шишацька» - традиційна 3 прив'язним утриманням корів у стійловий період та їх доїнням у молокопровід. Годівля корів обох стад однакова у відповідності до їх фізіологічного стану.

Роль бугая у підвищенні молочної продуктивності дочок вивчали в умовах прогресивної технології виробництва молока (ТОВ «Гоголево»). Досліджували продуктивність корів, які були дочками плідників Б.Е.Кенні 63285238, Б.Патча 61980169, В.В.Аллегро 13120690, Л.Марселлюса 136057831, Р.Поттера 62564884, Рексфорда 135644455 , С.Д.Ларіата 62398865 та Х.Віндбрейкера 132449988. Надій корів за 305 днів першої і другої лактації, вміст жиру в молоці, а також кількість молочного жиру визначали за використання електронної інформаційної бази ТОВ «АФ ім. Довженко» агрохолдингу «Астарта-Київ» у форматі СУМС “Інтесел-Орсек" за 2017 рік.

Мінливість ліній Белла 1667366, Элевейшна 1491007, Маршала 229097, Старбака 352790 і Чіфа 1427381 за надоєм визначали за розрахованого коефіцієнту варіації [5].

Для подальшої селекції за молочною продуктивністю в стадах української чорно-рябої молочної породи, нами доцільним вбачалося визначити консолідованість тварин тих само ліній, які утримувалися в різних господарствах та технологій виробництва молока. Для чого визначали коефіцієнт фенотипової консолідації за запропонованою Ю.П.Полупаном з співавторами формули [18].

Опрацювання експериментальних даних проводили методами математичної статистики засобами програмного пакету «Statistika 6.0» на ПК [2].

Результати досліджень. Оцінка впливу найбільш істотного генотипового чинника на молочну продуктивність корів - бугая, засвідчила неоднорідність одержаних показників, яку можна віднести саме до селекційної цінності батька потомства, оскільки усі фрактори довкілля були аналогічними і відповідали вимогам сучасного виробництва молока. У результаті наших досліджень в умовах прогресивної технології виробництва молока підтверджена значна різниця надою первісток, дочок 15 плідників голштинської породи, хоча у більшості випадків вона не достовірна. Варто зазначити, що первістки української чорно-рябої молочної породи у створених для них комфортних умовах утримання позитивно реагували на збалансований рівень годівлі у різні періоди лактації, що відобразилося у надою корів, який змінювався від 5847кг у потомків В.В.Аллегро до 8697кг Х.Віндбрейкера (табл. 1). При цьому дочки плідників В.В.Аллегро і Рексфорда за першу лактація продукували найменшу кількість молока, яка на 2850кг $(P>0,99)$ та 1787кг $(P>0,95)$ менша, порівняно до дочірніх нащадків бугая Х.Віндбрейкера і дещо менша - решти досліджуваних плідників. Прогресивна технологія виробництва молока у сумі із спадковістю бугаїв-поліпшувачів забезпечили коровам дочкам бугаїв Б.Е.Кенні, Б.Патча, В.Б.Секвойя, Д.Фрості, Л.Марселлюса, П.Гілморе, Р.Поттера, С.Д.Ларіата, С.Стінга і Х.Пеппера реалізаційний потенціал надою за 305 днів першої лактації понад 7000 кг молока, а Дж. А. Пінга і Х.Віндбрейкера - 8000 кг.

Тобто, автоматизація і механізація технологічних процесів, комп'ютиризований облік показників продуктивності у поєднанні з підбором плідників для відтворення

Вісник Сумського національного аграрного університету 
стада спряли високому прояву генетичного потенціалу надою корів української чорно-рябої молочної породи. Дещо нижчу продуктивність дочок плідників В.В.Аллегро і Рекс- форда за першу лактацію можна пояснити не вдалим поєднанням материнської та батьківської основи, а також спадковістю самих плідників.

Надій корів у залежності від походження за батьком

\begin{tabular}{|l|c|c|c|c|}
\hline \multicolumn{1}{|c|}{ Кличка та № бугая } & $\mathrm{n}$ & Надій корів першої лактації, кг & $\mathrm{n}$ & Надій корів другої лактації, кг \\
\hline Б.Е.Кенні 63285238 & 43 & $7876 \pm 198,4$ & 28 & $9992 \pm 199,1$ \\
\hline Б.Патч 61980169 & 72 & $7190 \pm 145,6$ & 69 & $9116 \pm 188,8$ \\
\hline В.Б.Секвойя 64188829 & 17 & $7757 \pm 395,2$ & 5 & $7962 \pm 976$ \\
\hline В.В.Аллегро 13120690 & 11 & $5847 \pm 420,5^{* *}$ & 11 & $7680 \pm 484,3$ \\
\hline Г.Б.Шотгун 103939456 & 16 & $8122 \pm 341,7$ & 3 & $9709 \pm 744,2$ \\
\hline Д.Фрості 131520543 & 26 & $7891 \pm 377,2$ & 9 & $8805 \pm 1084,2$ \\
\hline Дж.А.Пінг 61089329 & 10 & $8274 \pm 303,1$ & 5 & $10898 \pm 335,0$ \\
\hline Л.Марселлюс 136057831 & 34 & $7377 \pm 235,8$ & 17 & $8653 \pm 549,5$ \\
\hline П.Гілморе 137244467 & 10 & $7703 \pm 527,1$ & 3 & $8675 \pm 576,6$ \\
\hline Р.Поттер 62564884 & 18 & $7551 \pm 242,6$ & 10 & $9277 \pm 524,8$ \\
\hline Рексфорд 135644455 & 10 & $6910 \pm 517,7$ & \\
\hline С.Д.Ларіат 62398865 & 39 & $7585 \pm 275,2$ & 10 & $8450 \pm 515,5$ \\
\hline С.Стінг 7876687 & 26 & $7365 \pm 360,1$ & 17 & $9348 \pm 432,6$ \\
\hline Х.Віндбрейкер 132449988 & 19 & $8697 \pm 247,4$ & 8 & $8698 \pm 815,8$ \\
\hline Х.Пеппер 134904913 & 10 & $73934 \pm 410,5$ & 19 & $9566 \pm 324,5$ \\
\hline
\end{tabular}

Примітка: ${ }^{*}-P>0,95 ;{ }^{* *}-P>0,99$

Порівняльний аналіз бугаїв за молочною продуктивністю їх дочок корів української чорно-рябої молочної породи першої і другої лактації засвідчив зростання надою в динаміці, причому у окремих плідників досить значне, яке складно пояснити лише віком корів, оскільки інші чинники не змінилися. Істотним виявився вплив плідника і на надій корів другої лактації, за відсутності прямого зв'язку показнику між лактаціями. За другою лактацією найвищий реалізаційним потенціал своїм дочкам забезпечив бугай Дж. А. Пінг, від яких за 305 днів лактації одержано 10898кг молока, що на 2624кг (P>0,99) більше первісток. Не суттєво за другої лактації, порівняно із першою, підвищився надій у корів дочок плідника В.Б.Секвойя - лише на 205кг. Але найменшим надоєм другої лактації, як і першої, характеризувалися потомки бугая В.В. Аллегро, відповідно, 7680кг, хоча це й більше від первісток на 1833кг. Загалом, нами не встановлено чіткої закономірності підвищення надою другої лактації, порівняно із першою у залежності від походження за батьком, єдине, що можна констатував, так це те, що надій корів дійсно підвищувався із збільшенням кількості лактації.

Поряд із надоєм, важливою ознакою молочної продуктивності вважається вміст жиру в молоці, який у корів першої лактації становив $3,77-3,91 \%$ за не достовірної різниці між дочками досліджуваних плідників, що певною мірою можна пояснити не точністю визначення показнику впродовж лактації. Водночас кількість молочного жиру, яка теж може бути не зовсім точно визначеною за наявної оцінки жирномолочності, здебільшого узгоджувалася з надоєм корів за лактацію (табл. 2). За другою лактацією жирність молока корів різного походження за батьком знаходилася в межах 3,74- 4,02\%, хоча переважна більшість бугаїв забезпечила своїм дочкам вміст жиру на рівні 3,8-3,9\%. Загалом, бугаї за жирномолочністю другої лактації достовірно не різнилися між собою за аналогічної тенденції між показниками першої і другої лактації. Для переважної більшості бугаїв, за виключенням Б.Е. Кенні, В.В. Аллегро, Г.Б. Шотгуна, С.Д. Ларіата і Х. Пеппера, встановлено не значне, але зменшення вмісту жиру в молоці другої лактації, порівняно із першою.

Нашими дослідженнями встановлено, що найвищу кількість молочного жиру за другу лактацію - 419,3кг своїм дочкам забезпечив бугай Дж. А. Пінг, що на 31,6-123,8 кг більше, порівняно з іншими дослідженими плідниками. Кількість молочного жиру корів другої лактації мала таку ж спрямованість, як і першої лактації, тобто узгоджувалася із величиною надою корови за лактацію - чим вищий надій, тим більша кількість молочного жиру.

На нашу думку, виявлена різниця надою корів української чорно-рябої молочної породи, дочок досліджених бугаїв голштинської породи, які продукували молоко в умовах сучасної промислової технології, зумовлена саме племінною цінністю плідника та поєднанням його спадкової основи з спадковістю матері майбутнього потомства, оскільки природні чинники та рівень годівлі у тварин був однаковий. 3 урахуванням чого для подальшого прогресу стада за молочною продуктивністю потрібно використовувати бугаївполіпшувачів голштинської породи, оцінених за потомством, а також враховувати їх поєднуваність з коровами, потенційними матерями майбутнього потомства. 
Таблиця 2

Жирномолочність та кількість молочного жиру корів різного походження за батьком

\begin{tabular}{|l|c|c|c|c|c|c|}
\hline \multirow{2}{*}{ Кличка та № бугая } & \multirow{2}{*}{$\mathrm{n}$} & \multicolumn{3}{|c|}{ Перша лактація } & \multicolumn{3}{|c|}{ Друга лактація } \\
& & вміст жиру, \% & кількість молочного жиру, кг & & вміст жиру, \% & кількість молочного жиру, кг \\
\hline Б.Е.Кенні 63285238 & 43 & $3,86 \pm 0,02$ & $304,1 \pm 50,2$ & 28 & $3,89 \pm 0,03$ & $387,7 \pm 8,6$ \\
\hline Б.Патч 61980169 & 72 & $3,9 \pm 0,01$ & $280,4 \pm 49,0$ & 69 & $3,89 \pm 0,01$ & $354,3 \pm 7,4$ \\
\hline В.Б.Секвойя 64188829 & 17 & $3,9 \pm 0,02$ & $298,9 \pm 60,0$ & 5 & $3,82 \pm 0,05$ & $302,3 \pm 33,3$ \\
\hline В.В.Аллегро 13120690 & 11 & $3,85 \pm 0,03$ & $224,6 \pm 53,2$ & 11 & $3,85 \pm 0,05$ & $295,5 \pm 19,2$ \\
\hline Г.Б.Шотгун 103939456 & 16 & $3,89 \pm 0,02$ & $315,6 \pm 52,5$ & 3 & $4,02 \pm 0,02$ & $391,1 \pm 35,4$ \\
\hline Д.Фрості 131520543 & 26 & $3,94 \pm 0,03$ & $309,8 \pm 73,3$ & 9 & $3,81 \pm 0,03$ & $327,0 \pm 37,3$ \\
\hline Дж. А. Пінг 61089329 & 10 & $3,87 \pm 0,04$ & $304,4 \pm 34,8$ & 5 & $3,85 \pm 0,03$ & $419,3 \pm 14,5$ \\
\hline Л.Марселлюс 136057831 & 34 & $3,88 \pm 0,01$ & $287 \pm 50,5$ & 17 & $3,81 \pm 0,02$ & $331,1 \pm 21,9$ \\
\hline П.Гілморе 137244467 & 10 & $3,9 \pm 0,02$ & $300,4 \pm 64,5$ & 3 & $3,89 \pm 0,01$ & $337,6 \pm 21,6$ \\
\hline Р.Поттер 62564884 & 18 & $3,77 \pm 0,08$ & $284,6 \pm 45,6$ & 10 & $3,74 \pm 0,09$ & $349,3 \pm 24,7$ \\
\hline Рексфорд 135644455 & 10 & $3,86 \pm 0,04$ & $266,2 \pm 60,6$ & 10 & $3,84 \pm 0,02$ & $324,5 \pm 19,9$ \\
\hline С.Д.Ларіат 62398865 & 39 & $3,86 \pm 0,01$ & $292,9 \pm 65,7$ & 17 & $3,88 \pm 0,03$ & $362,3 \pm 16,2$ \\
\hline С.Стінг 7876687 & 26 & $3,86 \pm 0,03$ & $283,8 \pm 68,7$ & 8 & $3,82 \pm 0,05$ & $308,2 \pm 26,6$ \\
\hline Х.Віндбрейкер 132449988 & 19 & $3,91 \pm 0,03$ & $340,2 \pm 45,6$ & 19 & $3,89 \pm 0,02$ & $372,1 \pm 13,0$ \\
\hline Х.Пеппер 134904913 & 10 & $3,89 \pm 0,02$ & $287,3 \pm 49,6$ & 8 & $3,99 \pm 0,02$ & $386,1 \pm 29,4$ \\
\hline
\end{tabular}

Створення нових порід великої рогатої худоби за використання голштинської породи зумовило дослідження молочної продуктивності корів різних ліній [13, 22, 23], які продовжуються й до цього часу і носять часто дискусійний характер щодо переваги корів тих самих ліній у різних господарствах. Дослідженнями науковців доведено, що ступінь впливу належності до лінії голштинської породи на мінливість ознак молочної продуктивності має значні межі варіації $[1,23,30]$, що зумовлює пошук найбільш продуктивної лінії для кожного стада. Особливу зацікавленість викликають дослідження визначення впливу належності до лінії на молочну продуктивність корів за різних технологій виробництва молока. Нашими дослідженнями було встановлено, що найбільш високою молочною продуктивністю за безприв'язного способу утримання характеризувалися первістки і корови з третьою лактацією, які відносилися до лінії Елевейшна. Їх надій за 305 днів лактації становив, відповідно, 7913 кг і 10276 кг молока. Низькою продуктивністю першої і третьої лактації характеризувалися корови лінії Старбака 7493 кг і 8575 кг молока. Утримання корів на прив'язі забезпечило найбільш високі надої первісткам і з коровам з третьою лактацією, які належали до лінії Маршала, відповідно, 7059 кг і 8128 кг молока. Низькопродуктивними при даному способі утримання виявилися дочки плідників лінії Белла [4].

Виходячи з чого для визначення ефективності добору корів за молочною продуктивністю в умовах прогресивної та традиційної технології виробництва молока нами була поставлена мета дослідити міжлінійну диференціацію за надоєм та встановити вплив технології на створення однорідного стада.

Нами доведена не однорідність досліджуваних ліній за надоєм у межах різних господарств, підтвердженням чого слугує коефіцієнт мінливості, який в умовах безприв'язного утримання становив 15,8 -23,9\%, а прив'язного, відповідно, 15,3 -21,3\% (табл.3), засвідчуючи можливість селекції практично в кожному генеалогічному фрормуванні.

Таблиця 3

Коефіцієнт мінливості та консолідованості ліній

\begin{tabular}{|l|c|c|c|c|c|c|}
\hline \multirow{2}{*}{ Лінія } & \multicolumn{3}{|c|}{ Прогресивна технологія } & \multicolumn{3}{|c|}{ Традиційна технологія } \\
\cline { 2 - 7 } & $\mathrm{n}$ & $\mathrm{Cv}, \%$ & $\mathrm{~K}_{1}$ & $\mathrm{n}$ & $\mathrm{C}, \%$ & \multicolumn{1}{c|}{$\mathrm{K}_{1}$} \\
\hline Белла 1667366 & 18 & 15,8 & 0,233 & 14 & 15,3 & 0,238 \\
\hline Элевейшна 1491007 & 87 & 20,9 & $-0,072$ & 102 & 20,5 & $-0,080$ \\
\hline Маршала 2290977 & 117 & 21,0 & $-0,061$ & 85 & 18,5 & $-0,024$ \\
\hline Старбака 352790 & 119 & 23,9 & $-0,159$ & 90 & 21,3 & $-0,086$ \\
\hline Чіфра 1427381 & 192 & 19,3 & 0,057 & 117 & 19,2 & $-0,047$ \\
\hline
\end{tabular}

Примітка: Cv - коефріцієнт мінливості; К - коефіцієнт фенотипової консолідації

Найбільш фенотипово не однорідною за надоєм при різних технологіях виробництва молока була лінія Старбака 352790 , що на нашу думку узгоджується із значною кількістю плідників, використаних для відтворення стад, різною племінною цінністю бугаїв, різною віддаленістю від родоначальника лінії, що розсіяло його спадковість і привело до значних розбіжностей показників. Лінія Белла 1667366, яка налічувала найменше корів у стадах, характеризувалися не високим надоєм за значно меншого, порівняно з рештою досліджених ліній, коефіцієнту мінливості ознаки. Вірогідно в цій лінії буде складно поліпшити молочну продуктивність лише методами добору, хоча за такої кількості тварин висновок може бути не об'єктивним.

Загалом, визначений коефіцієнт мінливості ліній двох стад з різною технологією виробництва молока вказує на суттєву варіабельність генеалогічних формувань за надоєм в межах стада, яка значно перевищувала різницю між одними і тими ж лініями, але різних господарств. Так, наприклад, коефіцієнт мінливості лінії Белла за прогресивної технології становив 15,8\%, а за традиційної -15,3\%, Елевейшна, відповідно, 20,9\% і 20,5\% і так для решти ліній. Тобто, істотної різниці між фенотиповою мінливістю одних і тих сама ліній в різних господарствах практично немає. На підставі чого зроблено висновок про відсутність впливу умов утримання тварин на мінливість ліній за молочною продуктивністю. На нашу думку, мінливість лінії обумовлюється племінною цінністю родоначальника та продовжувачів лінії, а також успадковуваністю ознаки в стаді. 
Оцінка фенотипової консолідованості $\left(K_{1}\right)$ досліджуваних ліній за надоєм побічно узгоджувалася із коефіцієнтом мінливості генеалогічних формувань, вказуючи на наявністю як консолідованих груп в стаді, так і навпаки, не однорідних. За традиційної технології виробництва молока однорідною за надоєм була лише лінія Белла1667366, коефіцієнт консолідованості якої становить 0,238 (табл.3). Решта ліній в стаді з традиційною технологією виробництва молока, а саме Елевейшна, Маршала, Старбака і Чіфа були генотипово і фенотипово не однорідними, що підтверджено коефріцієнтом консолідації, який знаходився в площині $-0,024 \ldots$ 0,084. За прогресивної технології виробництва молока не консолідованими за надоями були лінії Елевейшна, Маршала і Старбака, коефіцієнт фенотипової консолідації (К근 яких становив відповідно, - 0,072; - 0,061 і - 0,159. До генотипово і фенотипово однорідних за сучасного виробництва молока віднесено лінії Белла і Чіфа. Загалом, визначений рівень фенотипової консолідованості ліній за надоєм засвідчив значну мінливість більшості селекційних груп двох стад, що слугуватиме підгрунттям для формування високопродуктивного стада методами селекції. Подібність коефіцієнта фенотипової консолідації тих само генеалогічних формувань, але різних стад, за виключенням Чіфа 1427381, на нашу думку доводить, що консолідованість тварин за надоєм не залежить від прийнятої технології виробництва молока, а обумовлена спадковістю представників відповідної лінії.
Висновки. Виявлено істотний вплив походження за батьком на формування молочної продуктивності корів української чорно-рябої молочної породи. Прогресивна технологія виробництва молока у сумі із племінною цінністю бугаїв-поліпшувачів забезпечили дочірнім нащадкам бугаїв Б.Е.Кенні, Б.Патча, В.Б.Секвойя, Д.Фрості, Л.Марселлюса, П.Гілморе, Р.Поттера, С.Д.Ларіата, С.Стінга і Х.Пеппера надій першої лактації понад 7000 кг молока, а Дж. А. Пінга і Х.Віндбрейкера -8000 кг.

Дослідженнями не встановлено чіткої закономірності підвищення надою другої лактації, порівняно із першою залежно від походження за батьком за його закономірного підвищення із збільшенням кількості лактації.

Встановлена значна мінливість генеалогічних формувань за надоєм у межах конкретного стада за одночасної відсутності значущої різниці між одними й тими ж лініями різних стад, що вилучає основний чинник середовища утримання тварин з-поміж фракторів впливу на варіабельність ліній.

Визначений рівень фенотипової консолідованості ліній за надоєм доводить можливість формування високопродуктивного стада методами селекції. Одночасно доведена відсутність впливу технології виробництва молока на консолідованість усіх досліджених ліній за надоєм , за виключенням Чіфра 1427381

\section{Список використаної літератури:}

1. Бондаренко Г. П. Вплив лінійної належності на молочну продуктивність корів української чорно-рябої молочної породи. Розведення і генетика тварин. К.: Аграрна наука, 2005. Вип. 38. С. 132-135. $2001.56 \mathrm{C}$.

2. Боровиков B. STATISTICA. Искусство анализа данных на компьютере: для профессионалов. Санкт-Петербург,

3. Войтенко С.Л., Сидоренко О.В., Вишневський Л.В. Селекційні досягнення у тваринництві України та видатні учені кінця XX початку XXI сторіччя. Полтава, 2019. 78c

4. Войтенко С.Л., Желізняк І.М. Надій корів у залежності від лінійної належності та способу утримання. Розведення $і$ генетика тварин. К.: Аграрна наука, 2019. Вип. 57. С. 38-44. doi.org.10.31073.abd/57.05

5. Войтенко С.Л., Петренко М.О., Вишневський Л.В. Практикум з селекції сільськогосподарських тварин. Полтава: ФОП Гаража М.Ф., 2016. 252с.

6. Войтенко С. Л., Петренко М. О., Шаферівський Б. С., Желізняк І. М. Молочна продуктивність та відтворна здатність корів української чорно-рябої молочної породи Полтавщини. Вісник Сумського Національного аграрного університету. Суми, 2017.Вип. 5/1 (31). С.36-44.

7. Голубев А., Мухтаров А. Молочная продуктивность коров при разных вариантах подбора . Молочное и мясное скотоводство. 2011. № 8. С. 26-27.

8. Ефименко М. Я. Формирование внутрипородной структуры создаваемых пород молочного скота . Розведення генетика тварин. К.: Аграрна наука, 2012. Вип. 46. С. 50-53

9. Коваленко Г. С., Бірюкова О.Д.Сучасний стан розведення за лініями в українській чорно-рябій молочній породі. Розведення і генетика тварин. К.: Аграрна наука, 2005. Вип. 38. С. 152-158

10. Костенко О. Вирішальні фактори в молочному скотарстві. Аграрний тиждень. 2015. № 4-5. С. 74-75

11. Кругляк А. П. Шляхи генетичного удосконалення та консолідації української червоно-рябої молочної породи. Розведення і генетика тварин. К.: Аграрна наука,1996. Вип. 28. С. 83-89.

12. Кругляк Т. О. Мінливість племінної цінності бугаїв-поліпшувачів. Розведення і генетика тварин. К.: Аграрна наука, 2014. Вип. 48. С. 80-84

13. Любинський О. Оцінка системи селекції та формування генеалогічної структури прикарпатського внутріпорідного типу української червоно-рябої молочної породи. Тваринництво України. 2005. № 8. С. 21-23.

14. Олешко В. П. Ефективність використання бугаїв-плідників у племінних стадах молочної худоби. Розведення і генетика тварин. К.: Аграрна наука, 2010. Вип. 44. С. 135-139.

15. Петренко І. П., Кругляк А. П., Гавриленко М. С., Кругляк Т. О. До питання успадкування племінної цінності тварин у скотарстві. Вісник аграрної науки Причорномор'я. Миколаїв, 2012. Вип. 4 (69), Т. 2. Ч. 1. С. 120-124.

16. Попков Н. А., Карсека И. В., Тимошенко В. Н. и др. Современные системы и способы содержания животных. Ефективне тваринництво. 2007. № 7 (23). С. 17-24

17. Полупан Ю. П., Петренко І. П. Теоретичні та практичні аспекти проблеми консолідації порід і типів тварин та оцін- 
ки препотентності плідників . Генетика і селекція в Україні на межі тисячоліть. К. : Логос, 2001. Т. 4. С. 116-137.

18. Полупан Ю. П., Рєзникова Н. Л. , Полупан Н. Л. Методика оцінки ступеня фенотипової консолідованості селекційних груп тварин на популяційному рівні. Розведення і генетика тварин. К. : Аграрна наука, 2011. Вип. 45. С. 207-216.

19. Приймич В.., Мамчак І.В. Молочна продуктивність корів-первісток української чорно-рябої породи в умовах промислової технології. Науковий вісник Львівської державної академії ветеринарної медицини ім. С. 3. Гжицького: Львів, 2000. T. 2 (№ 2). Ч. 3. С. 136-138.

20. Рудик І.А., Бірюкова О.Д., Басовський М.З. Генетичний потенціал української чорно-рябої молочної породи. Вісник аграрної науки. 2004. Вип. 6. С. 24-28.

21. Рудик І.А., Ставецька Р.В. Консолідованість та спорідненість ліній голштинської породи в Україні. Технологія виробництва і переробки продукції тваринництва. Біла Церква, 2010. Вип. 3 (72). С. 3-8.

38. C. $74-77$

22. Сірацький Й.3. Робота з лініями в сучасних умовах. Розведення і генетика тварин . К.: Аграрна наука, 2005. Вип.

23. Ставецька Р.В., Буштрук М.В., Старостенко І.С. та ін. Ефективність розведення за лініями в популяціях молочної худоби. Науковий вісник Національного університету біоресурсів і природокористування. Київ, 2013.Вип. 190. С. $298-304$.

24. Рєзникова Н. Л. Порівняльний аналіз впливу окремих середовищних чинників на деякі господарськи корисні ознаки молочних корів. Вісник аграрної науки. 2010. № 3. С. 32-34.

25. Сельцов В. И., Сермягин А. А. Генетическая и паратипическая обусловленность хозяйственно-полезных признаков у коров симментальской породы. Зоотехния. 2012. № 11. С. 4-7.

26. Скляренко Ю. І. Консолідація сумського внутрішньопородного типу української чорно-рябої молочної породи за основними селекційними ознаками. Вісник Сумського національного аграрного університету. Суми, 2007. Вип. 3 (12). C. $83-85$.

27. Трішин О., Микитюк Д., Білоус Д., Геймор М. Енергозберігаюча технологія виробництва молока. Пропозиція. 2005. № 8-9. C. 114-117.

28. Тележенко Е. В., Смирнова О. В. Генетика для рентабельности. Современная селекция как фактор устойчивого развития в молочном животноводстве. Тваринництво сьогодні. 2014. № 5. С. 20-25.

29. Хмельничий Л.М., Салогуб А.М., Жмурко С.М., Корнієнко Т.І., Котов Б.В., Сіряченко О.О., Соколов А.Ю. Генотипові та паратипові чинники впливу на ознаки молочної продуктивності корів молочних порід сумського регіону. Вісник Сумського національного аграрного університету. Суми, 2011. Вип.7 (19). С.25-29.

30. Федорович Є. І., Сірацький Й. 3. Західний внутрішньопородний тип української чорно-рябої молочної породи: господарсько-біологічні та селекційно-генетичні особливості. К. : Науковий світ, 2004. 385 с.

31. Ящук Т. С., Тихонова Б. Є. Вплив генотипних чинників на тривалість експлуатації корів української чорно-рябої молочної породи. Вісник аграрної науки. 2011. № 11. С. 47-51.

\section{References:}

1. Bondarenko, H.P., 2005. Vplyv liniinoi nalezhnosti na molochnu produktyvnist koriv ukrainskoi chorno-riaboi molochnoi porody [Influence of linear affiliation on dairy productivity of cows of Ukrainian black-rumped dairy breed]. Rozvedennia $i$ henetyka tvaryn, issue 38, pp. 132-135.

2. Borovikov, V., 2001. STATISTICA. Isskustvo analiza dannykh na komp'yutere: dlya professionalov [STATISTICS: Art of computer data analysis: for professionals]. S.-Peterburg.

3. Voitenko, S.L., Sydorenko, O.V., and Vyshnevskyi, L.V., 2019. Selektsiini dosiahnennia u tvarynnytstvi Ukrainy ta vydatni ucheni kintsia XX pochatku XXI storichchia [Breeding achievements in animal husbandry of Ukraine and outstanding scientists of the end of XX beginning of XXI century]. Poltava.

4. Voitenko, S. L. and Zhelizniak, I..M., 2019. Nadii koriv u zalezhnosti vid liniinoi nalezhnosti ta sposobu utrymannia [Hope for cows, depending on linear affiliation and method of keeping]. Rozvedennia $i$ henetyka tvaryn, issue 57, pp. 38-44. doi.org.10.31073.abd/57.05

5. Voitenko, S.L., Petrenko, M.O. and Vyshnevskyi L.V., 2016. Praktykum z selektsii silskohospodarskykh tvaryn [ Workshop on selection of farm animals]. Poltava.

6. Voitenko, S. L., Petrenko, M. O., Shaferivskyi, B. S. and Zhelizniak I. M., 2017. Molochna produktyvnist ta vidtvorna zdatnist koriv ukrainskoi chorno-riaboi molochnoi porody Poltavshchyny [ Dairy productivity and reproductive capacity of cows of Ukrainian black-rumped dairy breed of Poltava region]. Visnyk Sumskoho natsionalnoho ahrarnoho universytetu, issue 5/1 (31), pp. 36-44.

7. Golubev, A. and Muhtarov A., 2011. Molochnaya produktivnost korov pri raznyih variantah podbora [Milk productivity of cows with different selection options]. Molochnoe i myasnoe skotovodstvo, no. 8, pp. 26-27.

8. Efimenko, M. Ya., 2012. Formirovanie vnutriporodnoy strukturyi sozdavaemyih porod molochnogo skota [Formation of the in-breed structure of breeds of dairy cattle]. Rozvedennia i henetyka tvaryn, issue 46, pp. 50-53.

9. Kovalenko, H.S. and Biriukova, O. D., 2005. Suchasnyi stan rozvedennia za liniiamy v ukrainskii chorno-riabii molochnii porodi [The current state of line breeding in the Ukrainian black-tailed dairy breed]. Rozvedennia i henetyka tvaryn, issue 38, pp.152158. pp.74-75.

10. Kostenko, O., 2015. Vyrishalni faktory v molochnomu skotarstvi [Crucial factors in dairy cattle]. Ahrarnyi tyzhden, no. 4-5,

11. Kruhliak, A.P., 1996. Shliakhy henetychnoho udoskonalennia ta konsolidatsii ukrainskoi chervono-riaboi molochnoi porody [Ways of Genetic Improvement and Consolidation of Ukrainian Red-breasted Breed]. Rozvedennia $i$ henetyka tvaryn, issue 
28, pp.83-89.

12. Kruhliak, T.O., 2014. Minlyvist pleminnoi tsinnosti buhaiv-polipshuvachiv[ Variability of breeding value of boogieenhancers]. Rozvedennia i henetyka tvaryn, issue 48, pp.80-84

13. Liubynskyi, O., 2005. Otsinka systemy selektsii ta formuvannia henealohichnoi struktury prykarpatskoho vnutriporidnoho typu ukrainskoi chervono-riaboi molochnoi porody [Evaluation of the system of breeding and formation of the genealogical structure of the Carpathian intrinsic type of Ukrainian red-speckled milk breed]. Tvarynnytstvo Ukrainy, no. 8, pp. 21-23.

14. Oleshko, V. P., 2010. Efektyvnist vykorystannia buhaiv-plidnykiv u pleminnykh stadakh molochnoi khudoby [Efficiency of use of booger-herds in breeding herds of dairy cattle]. Rozvedennia i henetyka tvaryn, issue 44, pp.135-139

15. Petrenko, I.P., Kruhliak, A.P., Havrylenko, M.S. and Kruhliak, T.O., 2012. Do pytannia uspadkuvannia pleminnoi tsinnosti tvaryn u skotarstvi [The question of inheritance of the breeding value of animals in cattle breeding]. Visnyk ahrarnoi nauky Prychornomoria, issue 4(69), vol. 2, part1, pp. 120-124

16. Popkov, N.A., Karseka, I.V., Timoshenko, V.N. and dr., (2007). Sovremennyie sistemyi i sposobyi soderjaniya jivotnyih [Modern systems and methods for keeping animals]. Efektyvne tvarynnytstvo, no. 7 (23), pp. 17-24.

17. Polupan Yu.P., Petrenko I.P., 2001. Teoretychni ta praktychni aspekty problemy konsolidatsii porid i typiv tvaryn ta otsinky prepotentnosti plidnykiv [Theoretical and practical aspects of the problem of consolidation of breeds and types of animals and assessment of the presentability of breeders]. Henetyka i selektsiia v Ukraini na mezhi tysiacholit, vol. 4, pp. 116-137.

18. Polupan, Yu. P., Rieznykova, N. L. and Polupan, N. L., 2011. Metodyka otsinky stupenia fenotypovoi konsolidovanosti selektsiinykh hrup tvaryn na populiatsiinomu rivni [Methods of estimation of the degree of phenotypic consolidation of animal breeding groups at the population level]. Rozvedennia i henetyka tvaryn, issue 45, pp.207-216.

19. Pryimych, V.I. and Mamchak, I.V., 2000. Molochna produktyvnist koriv-pervistok ukrainskoi chorno-riaboi porody v umovakh promyslovoi tekhnolohii [Dairy productivity of the first-born cows of the Ukrainian black-and-white breed in the conditions of industrial technology]. Naukovyi visnyk Lvivskoi derzhavnoi akademii veterynarnoi medytsyny im. S. Z. Hzhytskoho, vol. 2 (2), part 3, Lviv, pp.136-138.

20. Rudyk, I.A., Biriukova, O.D. and Basovskyi, M.Z., 2004. Henetychnyi potentsial ukrainskoi chorno-riaboi molochnoi porody [Genetic potential of Ukrainian black-and-white dairy breed]. Visnyk ahrarnoi nauky, no.6, pp.24-28

21. Rudyk, I.A. and Stavetska, R. V., 2010. Konsolidovanist ta sporidnenist linii holshtynskoi porody v Ukraini [Consolidation and affinity of Holstein lines in Ukraine]. Tekhnolohiia vyrobnytstva i pererobky produktsii tvarynnytstva, issue 3 (72), White Church, pp.3-8.

22. Siratskyi, Y.Z., 2005. Robota z liniiamy v suchasnykh umovakh [Working with lines in modern conditions]. Rozvedennia $i$ henetyka tvaryn, issue 38, pp.74-77.

23. Stavetska, R. V., Bushtruk M., V., Starostenko I. S. and in., 2013. Efektyvnist rozvedennia za liniiamy v populiatsiiakh molochnoi khudoby [Breeding efficiency by line in dairy cattle populations]. Naukovyi visnyk Natsionalnoho universytetu bioresursiv $i$ pryrodokorystuvannia, issue 190, pp. 298-304.

24. Rieznykova, N.L., 2010. Porivnialnyi analiz vplyvu okremykh seredovyshchnykh chynnykiv na deiaki hospodarsky korysni oznaky molochnykh koriv [Comparative analysis of the influence of individual environmental factors on some economically useful features of dairy cows]. Visnyk ahrarnoi nauky, no. 3, pp.32-34.

25. Seltsov, V.I. and Sermyagin, A.A., 2012. Geneticheskaya i paratipicheskaya obuslovlennost hozyaystvenno-poleznyih priznakov u korov simmentalskoy porodyi [Genetic and paratypic conditionality of economically useful traits in cows of Simmental breed]. Zootehniya, no.11, pp. 4-7

26. Skliarenko, Yu.l., 2007. Konsolidatsiia sumskoho vnutrishnoporodnoho typu ukrainskoi chorno-riaboi molochnoi porody za osnovnymy selektsiinymy oznakamy [Consolidation of the Sumy domestic breed type of Ukrainian black-rumped dairy breed by main breeding grounds]. Visnyk Sumskoho natsionalnoho ahrarnoho universytetu, issue 3 (12), pp.83-85.

27. Trishyn, O., Mykytiuk, D., Bilous, D. and Heimor, M., 2005.Enerhozberihaiucha tekhnolohiia vyrobnytstva moloka [Energy-saving milk production technology] . Propozytsiia, no.8-9, pp.114-117.

28. Telejenko, E.V. and Smirnova, O.V., 2014. Genetika dlya rentabelnosti. Sovremennaya selektsiya kak faktor ustoychivogo razvitiya $\mathrm{v}$ molochnom jivotnovodstve [Genetics for profitability. Modern breeding as a factor of sustainable development in dairy farming]. Tvarynnytstvo sohodni, no.5, pp. 20-25

29. Khmelnychyi, L.M., Salohub, A.M., Zhmurko, S.M., Korniienko, T.I., Kotov, B.V., Siriachenko O.O. and Sokolov, A.lu., 2011. Henotypovi ta paratypovi chynnyky vplyvu na oznaky molochnoi produktyvnosti koriv molochnykh porid sumskoho rehionu [Genotypic and paratypical factors influencing the milk production characteristics of dairy cows of Sumy region]. Bulletin of Sumy National Agrarian University, issue 7 (19), pp. 25-29.

30. Fedorovych, Ye.I. and Siratskyi, Y.Z., 2004. Zakhidnyi vnutrishnoporodnyi typ ukrainskoi chorno-riaboi molochnoi porody: hospodarsko-biolohichni ta selektsino-henetychni osoblyvosti [Western intra-breed type of Ukrainian black-and-white dairy breed: economic-biological and breeding-genetic features]. Kyiv: The scientific world.

31. lashchuk, T.S. and Tykhonova, B.Ye., 2011. Vplyv henotypnykh chynnykiv na tryvalist ekspluatatsii koriv ukrainskoi chorno-riaboi molochnoi porody [Influence of genotypic factors on the duration of operation of cows of Ukrainian black-rumped dairy breed]. Visnyk ahrarnoi nauky, no.11, pp. 47-51. 


\begin{abstract}
Zheliznyak I.M., Voitenko S.L.,

Karunna T.I.

Possibility of increasing dairy productivity of cows of Ukrainian black-spotted dairy breed due to breeding and technological factors.

Given that productivity gains cattle, largely due to the patterns of genotype animals in certain conditions, we found it relevant to connect the bull with the dairy productivity of daughters who produced milk in today's progressive technology and a balanced level of feeding, as well as the impact of technology on variability and consolidation of yield. Research has established that a progressive milk production technology in combination with the breeding value of bull-enhancers provided the cows with the bull daughters B.E. Kenney, B. Patch, V.B. Sekvoy, D. Frosti, L. Marsellus, P. Gilmore, R. Potter, S. D. Lariat, S. Stingand H. Pepper potential yield first lactation more than $7000 \mathrm{~kg}$ of milk, and John. A. Diagnostics H. Windbreaker - $8000 \mathrm{~kg}$. Low dairy productivity of daughters of single breeders probably due to the incompatibility of the parental base and the low tribal the value of the bull themselves. Not set clear patterns of increasing milk yield of cows of the second lactation, as compared to the first, depending on the parentage. Highest the realization potential of the second lactation milk was provided to his daughters by the bull J.A. Ping, whose yield within 305 days of lactation made $10898 \mathrm{~kg}$ of milk, which is $2624 \mathrm{~kg}(P>0,99)$ more the firstborn. A comparative analysis is of the variability of the same yield lines confirmed there is no significant difference between breeding groups within a particular holding a significant difference between herds, which led to the conclusion that there was no impact technologies of milk production for line variability. Defined phenotypic level the consolidation of the line of profit was not evidenced by the homogeneity of most genealogists formations within the herd, but it is recognized that the animals are consolidate don the return does not depend on the adopted technology of milk production, but is due to others factors.
\end{abstract}

Key words: cow, line, dairy productivity, influence of bull, technology, volatility and phenotypic consolidation.

Дата надходження до редакції: 11.09.2019 p. 